\title{
24th Dubrovnik Economic Conferences Symposium
}

\author{
Paul Wachtel ${ }^{1} \cdot$ Boris Vujčić ${ }^{2}$ \\ Published online: 16 April 2019 \\ (c) Association for Comparative Economic Studies 2019
}

This symposium includes three papers from Croatian National Bank's 24th annual Dubrovnik Economic Conference (DEC) held on June 2-5, 2018. The Croatian National Bank conferences have a well-established reputation for the presentation of excellent research on the changing world economy, and we are pleased to publish these papers which have been reviewed and revised for publication. We are grateful for comments provided by the discussants in Dubrovnik, Maja Bukovšak and Tomislav Ridzak, as well as by our anonymous referees.

The program committee for the 24th Dubrovnik Economic Conference was chaired by Dr. Boris Vujčić, Governor of the Croatian National Bank. The other committee members were Paul Wachtel, Professor of Economics at the Leonard N. Stern School of Business at New York University, Randall K. Filer, Professor of Economics at Hunter College of the City University of New York and at CERGEEI, Prague and Dr. Dubravko Mihaljek, Head of Macroeconomic Analysis, Bank for International Settlements. The selection committee for the Young Economists' Seminar which is held in conjunction with DEC consisted of Professors Randall K. Filer, Evan Kraft, American University and Paul Wachtel.

In addition to the papers published here, papers by Rainer Haselmann, Emily Blanchard, Marina Kunovac, Yuriy Gorodnichenko and Raphaël Franck were presented in Dubrovnik. These papers can be found at the Croatian National Bank web site: https://www.hnb.hr/-/the-24th-dubrovnik-economic-conference.

Paul Wachtel

Pwachtel@stern.nyu.edu

Boris Vujčić

bvujcic@hnb.hr

1 Stern School of Business, New York University, 44 West 4th Street, New York, NY 10012-1126, USA

2 Croatian National Bank, Trg hrvatskih velikana 3, 10002 Zagreb, Croatia 
Finally, the success of the Dubrovnik Economic Conference owes much to the efforts of Tomislav Presečan, Chief Operating Officer and the entire staff of the Croatian National Bank.

Publisher's Note Springer Nature remains neutral with regard to jurisdictional claims in published maps and institutional affiliations. 